\title{
GENOTYPIC DETECTION OF SOME PSEUDOMONAS AERUGINOSA VIRULENCE GENES AMONG DIFFERENT CLINICAL ISOLATES
}

\author{
Iman Salah Naga ${ }^{(1)}$, Shahad Abdulwahab Abdulrazzaq ${ }^{(2)}$, Dalia Metwally Ragab ${ }^{(1)}$ \\ (1) Department of Microbiology, Medical Research Institute, University of Alexandria \\ (2) Bachelor of clinical analysis, Almamoun University, Iraq
}

\begin{abstract}
Background. Pseudomonas aeruginosa an opportunistic pathogen that can infect virtually all tissues via a number of virulence factors and possess a variety of antibiotic resistance mechanisms.

The aim of this study was molecular identification of genus and species level of P. aeruginosa by detection of oprI, oprL genes respectively by PCR. Determination of antibiotic resistance profile among isolates, as well as, detection of virulence genes toxA, plcH, plcN and LasB by PCR. Identification and antimicrobial susceptibility of fifty $\mathrm{P}$. aeruginosa isolates obtained from different clinical specimens were performed on VITEK-2 Compact system. PCR was used for the molecular confirmation of genus and species level of P. aeruginosa by detection of oprI, oprL genes, as well as, the molecular detection of virulence genes toxA, $\mathrm{plcH}$, plcN and LasB.

The highest prevalence of resistance was detected against 3rd and 4th generation cephalosporins $(80 \%)$. Resistance to other $\beta$-lactam antibiotics including piperacillin-tazobactam, monobactams, imipenem and meropenem was $62 \%, 70 \%, 64 \%$ and $62 \%$ respectively. Resistance to aminoglycosides ranged from $44 \%$ to amikacin and $56 \%$ to tobramycin. High level of resistance $(68 \%)$ to fluoroquinolones was detected. All isolates showed susceptiblity to lipopolypeptide antibiotics, colistin and polymixin. Using multiplex PCR, all strains were confirmed molecularly as P. aeruginosa via detection of oprI, oprL genes in the $50(100 \%)$ isolates, plcH and plcN were detected in all $50(100 \%)$ of strains and toxA in $46(92 \%)$ and LasB in $50(100 \%)$ of strains each in separate PCR reactions.

This investigation is a thorough report of some virulence factors and antibiotic resistance properties of P.aeruginosa isolated from Egyptian human clinical samples. Results affirm that all tox $\mathrm{A}, \mathrm{lasB}, \mathrm{plcH}, \mathrm{plcN}$ genes are prevalent in human infections. Antibiotic resistance was high. Hence, judicious antibiotics usage is required by clinicians.
\end{abstract}

\section{INTRODUCTION}

Peudomonas aeruginosa is a motile, non-fermenting,Gram-negative bacteria from Pseudomonadaceae family. (1) $\backslash$ It is an opportunistic pathogen capable of infecting almost all tissues, and responsible for hospital acquired infections ${ }^{(2)}$.

Immunocompromised patients, burn patients, mechanically ventilated patients, leukemic and cystic fibrosis patients are particularly susceptible to $P$. aeruginosa infections ${ }^{(3)}$.

The critical attributes responsible for the pathogenic potential of $P$. aeruginosa are the production of a multitude of virulence factors, biofilm formation and antibiotic resistance ${ }^{(4)}$. These factors enable successful infection and colonization across a wide range of environments. This arsenal includes; elastase, phosphorlipase C (PLC) ${ }^{(5)}$, alkaline protease, exotoxin A, exoenzyme S, pyocyanin, pyoverdin, hydrogen cyanide, as well as cell-associated factors, such as alginate, lipopolysaccharide, flagella, pili $^{(6,7)}$.

Exotoxin A is the most toxic substance in $P$. aeruginosa, it catalyzes the ADP ribosylation of the eukaryotic elongation factor 2 (eEF-2), and thus significantly affects protein synthesis of the host cells ${ }^{(8)}$.

LasB elastase has an elastolytic activity on lung tissue. It is a zinc metalloprotease encoded by las $B$ gene $^{(9)}$. Moreover, the phospholipids in pulmonary surfactants may be hydrolysed by PLC-H and PLC-N, two phospholipases $\mathrm{C}$ encoded by $p l c H$ and $p l c N$ respectively ${ }^{(10)}$.

The outer membrane proteins of $P$. aeruginosa, OprI and OprL, are of major importance in the interaction of the bacterium with the surrounding and the inherent resistance of $P$ aeruginosa to antimicrobial agents (1i) As they are only detected in this organism, they are a reliable factor for rapid molecular identification of $P$. aeruginosa in clinical samples ${ }^{(12)}$. Although conventional microbiological techniques for identifying $P$. aeruginosa are dependable, they require a number days to be completed. Rapid identification of isolates is critical for subsequent treatment decision of patients. PCR has the potential for rapid identification of microbial species by amplification of unique sequences in a particular organism ${ }^{(6)}$.

Therefore, this study aimed for molecular identification of genus, species levels of $P$. aeruginosa by 
detection of oprI, oprL genes respectively by PCR. Determination of antibiotic resistance profile among isolates, as well as, detection of virulence genes toxA, plcH, plcN and LasB by PCR.

\section{Subjects and Methods:}

Fifty $P$. aeruginosa isolates were obtained from several clinical specimens after the approval of ethical committee of the Medical Research Institute, Alexandria University.

\section{Bacterial isolation, identification and storage:}

All specimens were cultured routinely on blood and MacConkey's agar. After overnight incubation, Gram negative, non-lactose fermenting oxidase positive colonies were further identified using VITEK-2 Compact system (GN-13 card) (bioMerieux, France). Isolates were stored in Luria Bertani ${ }^{(13)}$ broth containing $30 \%$ glycerol and tubes stored at $-80^{\circ} \mathrm{C}$. For bacterial revival, one loopful was streaked over blood agar and incubated at $37^{\circ} \mathrm{C}$.

\section{Antimicrobial Susceptibility testing of P.aeruginosa isolates:}

Antimicrobial susceptibility was performed on VITEK-2 Compact system (bioMerieux, France) according to manufacturer's instructions. The AST-NO21 cards and software were used for analysis.

\section{Polymerase chain reaction (PCR):}

PCR was used for the confirmation of genus as well as species level of $P$. aeruginosa by detection of oprI, oprL genes, moreover, detection of virulence genes toxA, plcH, plcN and LasB.

DNA extraction was performed by boiling method ${ }^{(14)}$. Briefly, 2 to 3 colonies from overnight cultured were suspended in TE buffer containing $0.1 \%$ triton X100. Bacterial suspensions were incubated in a boiling water bath for 15 minutes followed by rapid cooling on ice. After centrifugation for 15 minutes at $14,000 \mathrm{rpm}$ in a microfuge, the supernatant was served as a source for bacterial DNA.

PCR was carried out in $25 \mu \mathrm{l}$ final volume containing $12.5 \mu \mathrm{l}$ hot start PCR master mix MyTaq ${ }^{\mathrm{TM}}$ HS Red Mix (BioLine, London, UK), 10 pmole of each primer (all primers were purchased from Thermo Fisher Scientific, California., USA) (Table I) and $0.5 \mu \mathrm{l}$ bacterial DNA. A negative control was prepared by the addition of the same contents to the tube with water instead of the extract. All PCR reactions were performed on Veriti thermal cycler (Applied Biosystems, California, USA). oprI/oprL and plcH/plcN were detected in 2 multiplex PCR reactions, while toxA and las $B$ were detected using singleplex PCR.

The reactions were performed according to the following thermal profile, initial denaturation $95^{\circ} \mathrm{C}$ for 3 minutes followed by 40 cycles of denaturation at $95^{\circ} \mathrm{C}$ for 30 seconds, annealing for 15 seconds and extension at $72^{\circ} \mathrm{C}$ for $1 \mathrm{~min} / \mathrm{kb}$ followed by final extension at $72^{\circ} \mathrm{C}$ for 5 minutes. PCR products were separated by gel electrophoresis on $2 \%$ agarose gel containing $0.5 \mu \mathrm{g} / \mathrm{ml}$ ethidium bromide

Table (1): Primers used for the PCR reactions

\begin{tabular}{|c|c|c|c|c|}
\hline Primer & $\begin{array}{c}\text { Nucleotide Sequence } \\
\mathbf{5}^{\prime}-\mathbf{3}, \\
\end{array}$ & $\begin{array}{c}\text { Annealing } \\
\text { temperature }{ }^{\circ} \mathbf{C}\end{array}$ & $\begin{array}{l}\text { Amplicon } \\
\text { size (bp) }\end{array}$ & Reference \\
\hline oprI- F & CGTTCTGAAATTCTCTGCTATGAACAA & \multirow{2}{*}{55} & \multirow{2}{*}{249} & \multirow{2}{*}{$(15)$} \\
\hline oprI-R & CTTGCGGCTGGCTTTTTCCAG & & & \\
\hline oprL- F & ATGGAAATGCTGAAATTCGGC & \multirow{2}{*}{55} & \multirow{2}{*}{504} & \multirow{2}{*}{ (16) } \\
\hline oprL-R & CTTCTTCAGCTCGACGCGACG & & & \\
\hline plcH- F & GAAGCCATGGGCTACTTCAA & \multirow{2}{*}{55} & \multirow{2}{*}{307} & \multirow{8}{*}{ (17) } \\
\hline plcH -R & AGAGTGACGAGGAGCGGTAG & & & \\
\hline plcN - F & GTTATCGCAACCAGCCCTAC & \multirow{2}{*}{55} & \multirow{2}{*}{466} & \\
\hline plcN -R & AGGTCGAACACCTGGAACAC & & & \\
\hline toxA - F & GGTAACCAGCTCAGCCACAT & \multirow{2}{*}{56} & \multirow{2}{*}{352} & \\
\hline toxA -R & TGATGTCCAGGTCATGCTTC & & & \\
\hline lasB- F & GGAATGAACGAAGCGTTCTC & \multirow{2}{*}{55} & \multirow{2}{*}{300} & \\
\hline lasB-R & GGTCCAGTAGTAGCGGTTGG & & & \\
\hline
\end{tabular}




\section{RESULTS}

The $50 P$. aeruginosa isolates were isolated from 27 (54\%) females and $23(46 \%)$ males. Twenty (40\%) isolates were from respiratory tract infections, $15(30 \%)$ from wound infections, $8(16 \%)$ from bloodstream infections, and 7 (14\%) from urine samples.

\section{Molecular diagnosis of $P$. aeruginosa:}

Using multiplex PCR, all strains included in the current study were confirmed molecularly as $P$. aeruginosa via detection of oprI, oprL genes in the $50(100 \%)$ isolates.

\section{Molecular detection of $\boldsymbol{P}$. aeruginosa virulence genes:}

Using multiplex PCR, $p l c H$ and $p l c N$ were detected in all $50(100 \%)$ of strains and toxA in $46(92 \%)$ and $L a s B$ in 50 $(100 \%)$ of strains each in separate PCR reactions. ToxA gene was not detected in 2 samples from bloodstream infections, 1 from respiratory tract infection and 1 from wound infection.
Table (18) shows the antimicrobial susceptibility testing of the $50 \mathrm{P}$. aeruginosa isolates included in this study. The highest prevalence of resistance was detected against third and fourth generation cephalosporins (80\%). Resistance to other $\beta$-lactam antibiotics including piperacillin-tazobactam, monobactams, imipenem and meropenem was $62 \%, 70 \%, 64 \%$ and $62 \%$ respectively. Resistance to aminoglycosides ranged from $44 \%$ to amikacin and $56 \%$ to tobramycin. High level of resistance $(68 \%)$ to fluoroquinolones was detected. All isolates were susceptible to lipopolypeptide antibiotics, colistin and polymixin.

Table (III) shows the distribution of antimicrobial resistance among clinical samples. Resistance showed lower prevalence in urinary tract infections in comparison to other sites of infection. Additionally, resistance to $3^{\text {rd }}$ and $4^{\text {th }}$ generation cephalosporins recoded the highest prevalence among all infection sites.

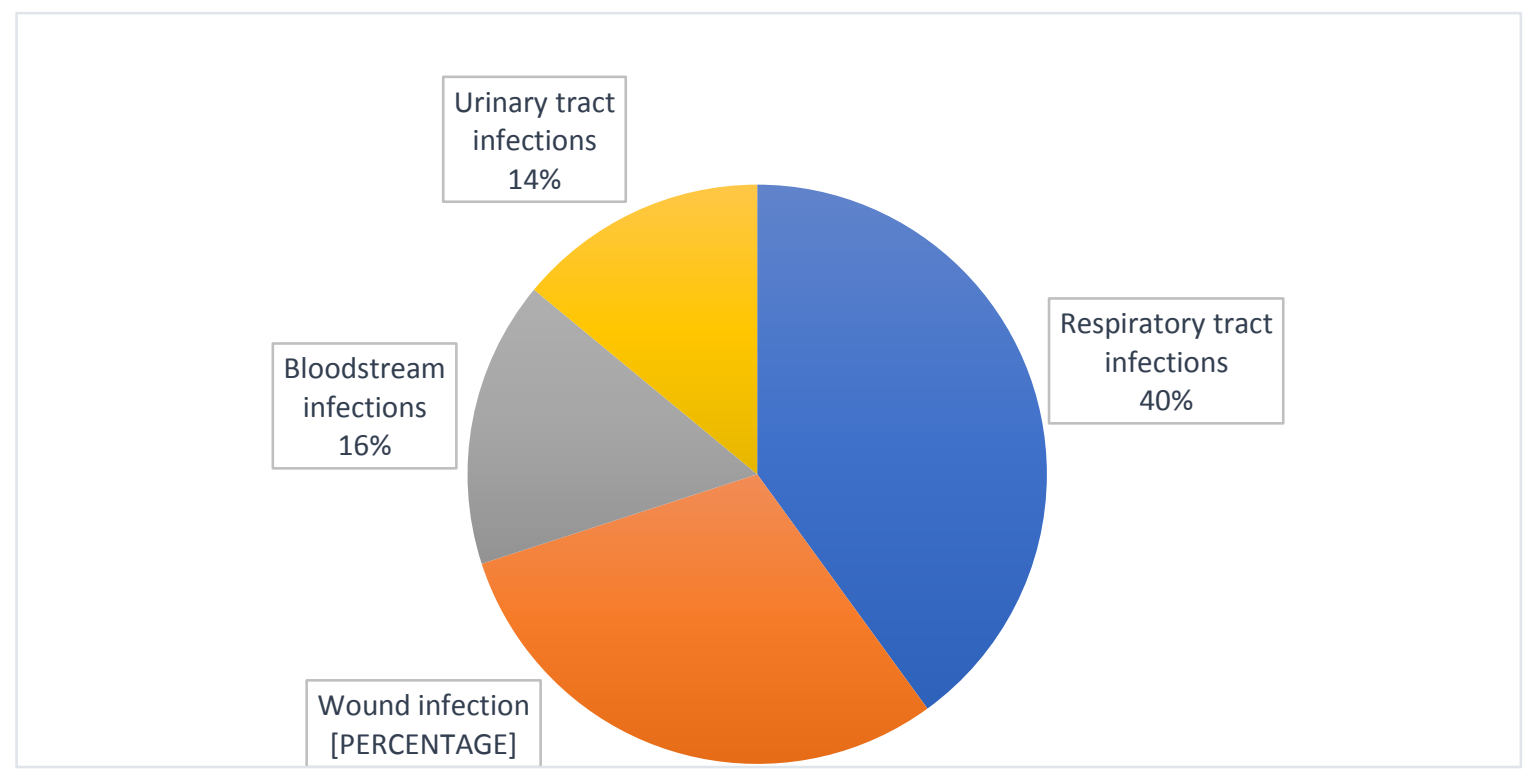

Figure (1): Distribution of the studied cases according to the site of isolation

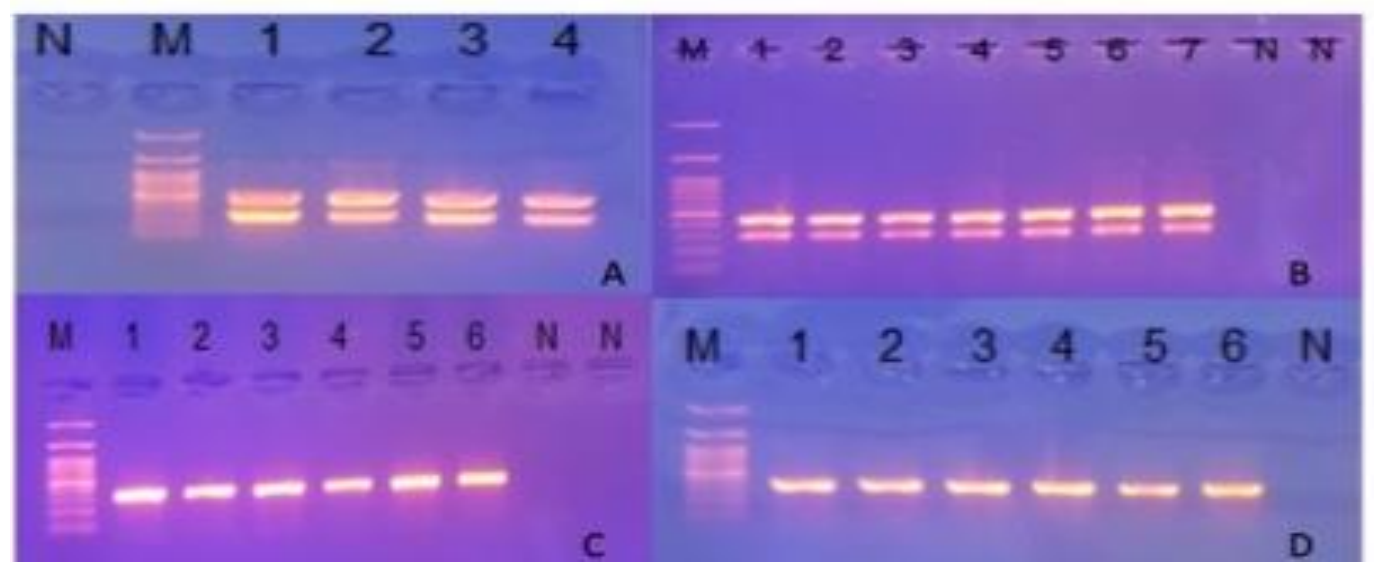

Figure (2):Ethidium bromide stained agarose gel showing the expected size of the amplified band of $\mathbf{A}=O p r I 249$ bp and $O p r L$ at 504 bp in lanes $1-4, \mathrm{~B}=\mathrm{PlcH}$ at $307 \mathrm{bp}$ band size and $\mathrm{PlcN}$ at $466 \mathrm{bp}$ in lanes 1-7, $\mathrm{C}=\mathrm{LasB}$ in lanes 1-6 at $300 \mathrm{bp}$ and $\mathrm{D}=$ toxA at $352 \mathrm{bp}$ in lanes 1-6. $\mathrm{M}$ is100bp DNA ladder. $\mathrm{N}$ shows the lanes where water replaced the template in the PCR as a negative control. 
Table (2) Antimicrobial susceptibility testing of the 50 P.aeruginosa isolates

\begin{tabular}{|c|c|c|c|c|c|c|}
\hline \multirow{2}{*}{$\begin{array}{l}\text { Antimicrobial } \\
\text { agent }\end{array}$} & \multicolumn{2}{|c|}{ Sensitive } & \multicolumn{2}{|c|}{ Intermediate } & \multicolumn{2}{|c|}{ Resistant } \\
\hline & No & $\%$ & No & $\%$ & No & $\%$ \\
\hline Piperacillin- & 15 & 30 & 4 & 8 & 31 & 62 \\
\hline \multicolumn{7}{|l|}{ Tazobactam } \\
\hline Ceftazidime & 8 & 16 & 2 & 4 & 40 & 80 \\
\hline Cefipime & 9 & 18 & 1 & 2 & 40 & 80 \\
\hline Aztreonam & 11 & 22 & 4 & 8 & 35 & 70 \\
\hline Imipenem & 18 & 36 & 0 & 0 & 32 & 64 \\
\hline Meropenem & 19 & 38 & 0 & 0 & 31 & 62 \\
\hline Gentamicin & 22 & 44 & 2 & 4 & 26 & 52 \\
\hline Tobramycin & 21 & 42 & 1 & 2 & 28 & 56 \\
\hline Amikacin & 27 & 54 & 1 & 2 & 22 & 44 \\
\hline Ciprofloxacin & 16 & 32 & 0 & 0 & 34 & 68 \\
\hline Levofloxaxin & 16 & 32 & 0 & 0 & 34 & 68 \\
\hline Colistin & 50 & 100 & 0 & 0 & 0 & 0 \\
\hline Polymixin & 50 & 100 & 0 & 0 & 0 & 0 \\
\hline
\end{tabular}

Table (3): Antimicrobial susceptibility testing of the 50 P.aeruginosa isolates

\begin{tabular}{|c|c|c|c|c|c|c|c|c|c|c|}
\hline & \multicolumn{2}{|c|}{ Respiratory tract } & \multicolumn{2}{|c|}{ Wound swab } & \multicolumn{2}{|c|}{ Blood } & \multicolumn{2}{|c|}{ Urine } & \multicolumn{2}{|c|}{ Total } \\
\hline & $\mathrm{N}=\mathbf{2 0}$ & $\%$ & $\mathrm{~N}=15$ & $\%$ & $\mathbf{N}=8$ & $\%$ & $N=7$ & $\%$ & $\mathbf{N}=\mathbf{5 0}$ & $\%$ \\
\hline Piperacillin- & 15 & 75 & 7 & 47 & 6 & 75 & 3 & 43 & 31 & 62 \\
\hline \multicolumn{11}{|l|}{ Tazobactam } \\
\hline Ceftazidime & 18 & 90 & 10 & 68 & 7 & 87.5 & 5 & 71 & 40 & 80 \\
\hline Cefipime & 18 & 90 & 10 & 68 & 7 & 87.5 & 5 & 71 & 40 & 80 \\
\hline Aztreonam & 16 & 80 & 10 & 68 & 5 & 87.5 & 4 & 57 & 35 & 70 \\
\hline Imipenem & 15 & 75 & 8 & 53 & 6 & 75 & 3 & 43 & 32 & 64 \\
\hline Meropenem & 15 & 75 & 8 & 53 & 5 & 62.5 & 3 & 43 & 31 & 62 \\
\hline Gentamicin & 13 & 65 & 6 & 40 & 4 & 50 & 3 & 43 & 26 & 52 \\
\hline Tobramycin & 14 & 70 & 6 & 40 & 5 & 62.5 & 3 & 43 & 28 & 56 \\
\hline Amikacin & 11 & 55 & 6 & 40 & 3 & 37.5 & 2 & 21 & 22 & 44 \\
\hline Ciprofloxacin & 16 & 80 & 9 & 60 & 6 & 75 & 3 & 43 & 34 & 68 \\
\hline Levofloxaxin & 16 & 80 & 9 & 60 & 6 & 75 & 3 & 43 & 34 & 68 \\
\hline Colistin & 0 & 0 & 0 & 0 & 0 & 0 & 0 & 0 & 0 & 0 \\
\hline Polymixin & 0 & 0 & 0 & 0 & 0 & 0 & 0 & 0 & 0 & 0 \\
\hline
\end{tabular}




\section{DISCUSSION}

P.aeruginosa as an opportunistic pathogen has different virulence factors which aid the bacteria to colonize different niches in their host and the bacteria are a leading cause of nosocomial and community-acquired infections worldwide $^{(19)}$. At present, bacterial culture remains the most commonly used method for detecting $P$. aeruginosa, but it is time-consuming and susceptible to conflicting results due to sample contamination. Also, this method has low sensitivity. Because of the significance of early diagnosis, direct detection of $P$. aeruginosa in clinical samples will reduce diagnostic turnaround time and minimize the risk of contamination ${ }^{(20)}$.

Identification of $P$. aeruginosa traditionally relies on phenotypic methods that still is the most accurate method. Biochemical testing takes long time to perform and requires extensive hands-on work, both for setup and for interpretation. Molecular methodologies have been reported to be superior to the phenotypic methods for identification of $P$. aeruginosa $\left.{ }^{(12,} 21\right)$. A designed multiplex PCR assay based on oprI and oprL genes for molecular confirmation of $P$. aeruginosa revealed that the specificity and sensitivity of PCR were 74 and $100 \%$, respectively. The main advantage of multiplex PCR is its ability to simultaneously amplify multiple PCR products in a single reaction, thereby enabling multiplex detection and significantly reducing the detection cost and time requirements ${ }^{(22)}$. Lavenir et al ${ }^{(23)}$ also stated that all of $P$. aeruginosa strains contained the oprI and oprL genes. Similarly El-Sheshtawy et al ${ }^{(24)}$ in their study reported that all of the 30 isolates were positive for both genes. This is consistent with this study result as both genes oprI, oprL were detected in all 50 (100\%) samples.

$P$. aeruginosa is capable of inducing different types of infections in humans. In the present study, twenty $(40 \%)$ $P$. aeruginosa isolates were obtained from respiratory tract infections, $15(30 \%)$ from wound, 8 (16\%) from bloodstream, and 7 (14\%) from urine tract infections.।

Viedma et $a l^{(25)}$ in their study showed that, $36(19.7 \%)$ suffered from lower respiratory tract infection, 30 (16.4\%) patients with urinary tract infection, $28(15.3 \%)$ patients with bloodstream infection and $22(12 \%)$ patients with intra-abdominal infection out of 183 patients. The high incidences of $P$. aeruginosa in respiratory infections have been previously reported in cystic fibrosis patients ${ }^{(26-28)}$.

The treatment of $P$. aeruginosa infections is significantly challenging. The diversity of antibiotic resistance mechanisms contributes to the development of multidrugresistant strains that make conventional antibiotics ineffective for therapy ${ }^{(29)}$.

In this study, antimicrobial resistance showed lower prevalence in urinary tract infections in comparison to respiratory, bloodstream and wound infections which may be attributed to community-acquired origin of infection. Additionally, resistance to third and fourth generation cephalosporins recoded the highest prevalence among all infection sites.

Fazeli et $a l^{(30)}$ in 2014 stated that their bacterial isolates were multidrug resistant. Resistance to gentamicin and ciprofloxacin was reported in $39.21 \%$ and $21.56 \%$ of their bacterial strains isolated from hospital infections. In another study by Fazeli et $a l^{(31)}$ including hospital acquired infections, hospital means and personnel's specimen, they showed that $29 \%$ and $32.2 \%$ of the $P$. aeruginosa strains were resistant to ciprofloxacin and gentamicin, which was much lower than our results. Lower resistance rates were reported in Latin America $26.8 \%{ }^{(32)}$ and $10 \%-32 \%$ in Europe ${ }^{(33,34)}$.

In a study of Viedma et $a l^{(25)}$, all the isolates were only susceptible to colistin (100\%) and amikacin (75\%). In this study colistin was also sensitive in all $100 \%$ of isolates.

The antibiotic resistant pattern found by Akingbade et al (35) investigation showed that $P$. aeruginosa, had low resistant to ceftazidime (20\%), gentamicin (26.4\%), levofloxacin $(30.9 \%)$, ceftriaxone $(34.5 \%)$, and ciprofloxacin $(35.5 \%)$, which was also much lower than our results. Similar results have been reported by Lim et $a l^{(36)}$ from Malaysia and Smith et $a l^{(37)}$ from Nigeria.

Pathogenicity of $P$. aeruginosa is multifactorial. LasB is one of the most important proteases of $P$. aeruginosa ${ }^{(38)}$, which causes direct injury to the lung early in the disease. Bleeding in the lung is often seen with pulmonary infections by $P$. aeruginosa due to the elastin breakdown in the blood vessels walls ${ }^{(39)}$. In this study, las $B$ gene was detected in all isolates. Nikbin et $\mathrm{al}^{(40)}$ in their study stated that all isolates harbored $\operatorname{las} B$ gene. This finding is in agreement with reports by Nicas et $a l^{(41)}$ and Lomholt et $a l^{(38)}$. Mutation of las $B$ gene reduces $P$. aeruginosa invasion remarkably. Prevalence of the las $B$ gene in all clinical isolates highlights its importance to of $P$. aeruginosa survival in various conditions ${ }^{(42)}$.

Toxin A has distinct role in hindering wound contraction and remedial ${ }^{(43)}$. Hummel and Unger ${ }^{(44)}$ established the first PCR method that detected $P$. aeruginosa based on the toxin A gene and evaluated its efficacy in mechanically ventilated patients. The results showed that the method detected 57 positive samples out of 364 total samples, whereas the conventional culture method only detected 36 positive samples, indicating that the toxin A gene-based PCR method had higher sensitivity. Using PCR, we detected toxinA gene in $100 \%$ of our isolates.

Phospholipase $\mathrm{C}$ plays a role in the lysis of target cells (pulmonary atelectasis) and is involved in acute and chronic infection $^{(45)}$. Most of the 151 isolates in a study performed by Elogne et al ${ }^{(10)}$ detected the virulence genes; plcH in $84.1 \%$ and $l a s B$ in $72.8 \%$. The plcH gene was found in all types of infections with prevalence ranging from $66.7 \%$ to $84.6 \%$. The highest prevalence was found in sepsis with $84.6 \%$ followed by lung infections with $81.5 \%$ and then urinary tract infections in $78.8 \%$. This 
frequency at the urinary level is close to that Heidary et al. $70.4 \%$ in 2016 in Iran ${ }^{(46)}$. Elastase causes the destruction of tissues containing elastin, tissue necrosis and haemorrhage ${ }^{(10)}$. The las $B$ gene was found in isolates from all infectious sites with variable rates. Prevalence were high and ranged from $57.1 \%$ to $81.5 \%$. The highest rate was found at the pulmonary level $(81.5 \%)$. These results are close to those of Mitov I. et al ${ }^{(47)}$ with $\mathrm{plcH}$ in (91.6) and lasB in $(100 \%)^{(47)}$. Similarly, in this study $\mathrm{plcH}$ and lasB were detected in all $100 \%$ of isolates.

On the other hand, the PCR results of virulence factor in the study by Al-Dahmoshi et al ${ }^{(48)}$ showed that exoA was present only among $12(46.15 \%)$, oprL was $11(42.3 \%)$, oprI was 22(84.61\%) and lasB was 18(69.23\%).

Coexistence of ExoA responsible for toxigenesis and LasB responsible for invasiveness makes both of mechanism of infection available and delays wound healing ${ }^{(49-52)}$. Coexistence of more than one virulence factor in the same isolate were recorded and the results displayed that $8 / 26$ have all five factors, 4/26 have four, $1 / 26$ have three and 5/26 have only two virulence factors (48). In this study, 46/50 samples had 4 virulence factors and only 4/50 had only 3 virulence factors, namely, plcH, plcN and las B.

Nikbin et al. in 2012 stated that all isolates carried oprI, oprL and lasB genes ${ }^{(40)}$. The presence of ExoA, OprL, OprI, LasI and LasB among P. aeruginosa isolates propose their association with different levels of virulence and pathogenicity ${ }^{(48,53)}$.

In summary, the study provides an insight into the phenotypic and genotypic characteristics of P. aeruginosa emerged in Egypt. Our finding highlighted a high rate of resistance to antibiotics. In order to reduce the risk of spread of highly resistant strains, we suggest the need to establish a periodic surveillance system, to enhance infection prevention and control measures in healthcare setting, and to increase awareness among physicians and the general public about the rational use of antibiotics. Future work should target mechanisms of resistance and genetic diversity of $\mathrm{P}$. aeruginosa strains to draw more far-reaching conclusions.

Further studies will be useful to affirm the correlation between the drug resistance pattern and virulence factor expression.

This study is a thorough report of virulence factors and antibiotic resistance properties of $P$. aeruginosa isolated from Egyptian human clinical samples. Our results disclosed that all tox $\mathrm{A}, \mathrm{lasB}, \mathrm{plcH}, \mathrm{plcN}$ genes are prevalent in human infections.

\section{REFERENCES}

1. .Lyczak JB, Cannon CL, Pier GB. Establishment of Pseudomonas aeruginosa infection: lessons from a versatile opportunist. Microbes Infect. 2000;2(9):1051-60.
2. Delden C, Iglewski BH. Cell-to-cell signaling and Pseudomonas aeruginosa infections. Emerg Infect Dis. 1998;4(4:551-60.

3. Fegan M, Francis P, Hayward AC, Davis GH, Fuerst JA. Phenotypic conversion of Pseudomonas aeruginosa in cystic fibrosis. J Clin Microbiol. 1990;28(6):1143-6.

4. Balasubramanian D, Schneper L, Kumari H, Mathee K. A dynamic and intricate regulatory network determines Pseudomonas aeruginosa virulence. Nucleic Acids Res. 2013;41(1):1-20.

5. Newman JW, Floyd RV, Fothergill JL. The contribution of Pseudomonas aeruginosa virulence factors and host factors in the establishment of urinary tract infections. FEMS Microbiol Lett. 2017;364(15).

6. Wagner $\mathrm{V}$, Filiatrault $\mathrm{M}$, Picardo $\mathrm{K}$, Iglewski $\mathrm{B}$. Pseudomonas aeruginosa virulence and pathogenesis issues. Pseudomonas: genomics and molecular biology/edited by Pierre Cornelis. 2008.

7. Rawat S, B P. Prevalence and characterization of virulence properties of pseudomonas aeruginosa from clinical samples and hospital environment in dehradun. Int J Biol Pharm Res. 2015;6:491-9.

8. Wolf P, Elsasser-Beile U. Pseudomonas exotoxin A: from virulence factor to anti-cancer agent. Int J Med Microbiol. 2009;299(3):161-76.

9. Benie CK, Dadie A, Guessennd N, N'Gbesso-Kouadio NA, Kouame ND, N'Golo D C, et al. Characterization of Virulence Potential of Pseudomonas Aeruginosa Isolated from Bovine Meat, Fresh Fish, and Smoked Fish. Eur J Microbiol Immunol (Bp). 2017;7(1):55-64.

10. Elogne CK, N'Guetta AKA, Yeo A, David CNg, Guessennd N, Anné JC, et al. Prevalence of Pseudomonas aeruginosa's Virulence Genes Isolated from Human Infection in Abidjan, Côte d'Ivoire. Microbiology Research Journal International. 2018;25 (1):1-8.

11. Nikaido H. Prevention of drug access to bacterial targets: permeability barriers and active efflux. Science. 1994;264(5157):382-8.

12. De Vos D, Lim A, Jr., Pirnay JP, Struelens M, Vandenvelde C, Duinslaeger L, et al. Direct detection and identification of Pseudomonas aeruginosa in clinical samples such as skin biopsy specimens and expectorations by multiplex PCR based on two outer membrane lipoprotein genes, oprI and oprL. J Clin Microbiol. 1997;35 (6): 1295-9.

13. Japoni A, Alborzi A, Kalani M, Nasiri J, Hayati M, Farshad S. Susceptibility patterns and cross-resistance of antibiotics against Pseudomonas aeruginosa isolated from burn patients in the South of Iran. Burns. 2006;32 (3):343-7.

14. Yang JL, Wang MS, Cheng AC, Pan KC, Li CF, Deng SX. A simple and rapid method for extracting bacterial DNA from intestinal microflora for ERIC-PCR detection. World J Gastroenterol. 2008;14(18):2872-6.

15. De Vos D, Lim A, Jr., De Vos P, Sarniguet A, Kersters $\mathrm{K}$, Cornelis P. Detection of the outer membrane lipoprotein $I$ and its gene in fluorescent and non-fluorescent pseudomonads: implications for taxonomy and diagnosis. J Gen Microbiol. 1993;139(9):2215-23.

16. Lim A, Jr., De Vos D, Brauns M, Mossialos D, Gaballa A, Qing D, et al. Molecular and immunological characterization of OprL, the $18 \mathrm{kDa}$ outer-membrane peptidoglycan-associated lipoprotein (PAL) of Pseudomonas aeruginosa. Microbiology. 1997;143 ( Pt 5):1709-16. 
17. Stover CK, Pham XQ, Erwin AL, Mizoguchi SD, Warrener $\mathrm{P}$, Hickey $\mathrm{MJ}$, et al. Complete genome sequence of Pseudomonas aeruginosa PAO1, an opportunistic pathogen. Nature. 2000;406(6799):959-64.

18. Kawaguchi T, Ide T, Koga H, Kondo R, Miyajima I, Arinaga-Hino T, et al. Rapidly growing hepatocellular carcinoma after direct-acting antiviral treatment of chronic hepatitis C. Clin J Gastroenterol. 2018;11(1):69-74.

19. de Bentzmann S, Plesiat P. The Pseudomonas aeruginosa opportunistic pathogen and human infections. Environ Microbiol. 2011;13(7):1655-65.

20. Tang Y, Ali Z, Zou J, Jin G, Zhu J, Yang J, et al. Detection methods for Pseudomonas aeruginosa: history and future perspective. RSC Advances. 2017;7(82): 51789-800.

21. Qin X, Emerson J, Stapp J, Stapp L, Abe P, Burns JL. Use of real-time PCR with multiple targets to identify Pseudomonas aeruginosa and other nonfermenting gramnegative bacilli from patients with cystic fibrosis. J Clin Microbiol. 2003;41(9):4312-7.

22. Mahony JB, Blackhouse G, Babwah J, Smieja M, Buracond S, Chong S, et al. Cost analysis of multiplex PCR testing for diagnosing respiratory virus infections. J Clin Microbiol. 2009;47(9):2812-7.

23. Lavenir R, Jocktane D, Laurent F, Nazaret S, Cournoyer B. Improved reliability of Pseudomonas aeruginosa PCR detection by the use of the species-specific ecfX gene target. J Microbiol Methods. 2007;70(1):20-9.

24. El-Sheshtawy NM, Khattab MA, Nour MS. Genetic Identification of Pseudomonas aeruginosa Virulence Genes among Different Isolates. J Microb Biochem Technol. 2015;7(5).

25. Viedma E, Juan C, Villa J, Barrado L, Orellana MA, Sanz F, et al. VIM-2-producing multidrug-resistant Pseudomonas aeruginosa ST175 clone, Spain. Emerg Infect Dis. 2012;18(8):1235-41.

26. West SEH, Zeng L, Lee BL, Kosorok MR, Laxova A, Rock MJ, et al. Respiratory Infections With Pseudomonas aeruginosa in Children With Cystic FibrosisEarly Detection by Serology and Assessment of Risk Factors. JAMA. 2002;287(22):2958-67.

27. Martinez-Solano L, Macia MD, Fajardo A, Oliver A, Martinez JL. Chronic Pseudomonas aeruginosa infection in chronic obstructive pulmonary disease. Clin Infect Dis. 2008;47(12):1526-33.

28. Tingpej P, Smith L, Rose B, Zhu H, Conibear T, Al Nassafi K, et al. Phenotypic characterization of clonal and nonclonal Pseudomonas aeruginosa strains isolated from lungs of adults with cystic fibrosis. J Clin Microbiol. 2007;45(6):1697-704.

29. Pang Z, Raudonis R, Glick BR, Lin TJ, Cheng Z. Antibiotic resistance in Pseudomonas aeruginosa: mechanisms and alternative therapeutic strategies. Biotechnol Adv. 2019;37(1):177-92.

30. Fazeli N, Momtaz H. Virulence Gene Profiles of Multidrug-Resistant Pseudomonas aeruginosa Isolated From Iranian Hospital Infections. Iran Red Crescent Med J. 2014;16(10):e15722.

31. Fazeli H, Akbari R, Moghim S, Narimani T, Arabestani MR, Ghoddousi AR. Pseudomonas aeruginosa infections in patients, hospital means, and personnel's specimens. J Res Med Sci. 2012;17(4):332-7.

32. Brown PD, Izundu A. Antibiotic resistance in clinical isolates of Pseudomonas aeruginosa in Jamaica. Rev Panam Salud Publica. 2004;16(2):125-30.

33. Bonfiglio G, Carciotto V, Russo G, Stefani S, Schito GC, Debbia E, et al. Antibiotic resistance in Pseudomonas aeruginosa: an Italian survey. J Antimicrob Chemother. 1998;41(2):307-10.

34. Bouza E, Garcia-Garrote F, Cercenado E, Marin M, Diaz MS. Pseudomonas aeruginosa: a survey of resistance in 136 hospitals in Spain. The Spanish Pseudomonas aeruginosa Study Group. Antimicrob Agents Chemother. 1999;43(4):981-2.

35. Akingbade O BS, Ojo D, Afolabi R, Motayo B, Okerentugba $\mathrm{P}$, et al. Plasmid profile analysis of multidrug resistant Pseudomonas aeruginosa isolated from wound infections in South West, Nigeria. orld Appl Sci J. 2012;20(6):766-75

36. Lim KT, Yasin RM, Yeo CC, Puthucheary SD, Balan G, Maning N, et al. Genetic fingerprinting and antimicrobial susceptibility profiles of Pseudomonas aeruginosa hospital isolates in Malaysia. J Microbiol Immunol Infect. 2009;42(3):197-209.

37. Smith S, Ganiyu O, John R, Fowora M, Akinsinde K, Odeigah P. Antimicrobial resistance and molecular typing of pseudomonas aeruginosa isolated from surgical wounds in Lagos, Nigeria. Acta Med Iran. 2012;50(6):433-8.

38. Lomholt JA, Poulsen K, Kilian M. Epidemic population structure of Pseudomonas aeruginosa: evidence for a clone that is pathogenic to the eye and that has a distinct combination of virulence factors. Infect Immun. 2001;69(10):6284-95.

39. N. Kapur KG, I.B. Masters, P.S. Morris, A.B. Chang. Lower airway microbiology and cellularity in children with newly diagnosed non-CF bronchiectasis. Pediatr Pulmonol. 2011;47(300e307).

40. Nikbin VS, Aslani MM, Sharafi Z, Hashemipour M, Shahcheraghi F, Ebrahimipour GH. Molecular identification and detection of virulence genes among Pseudomonas aeruginosa isolated from different infectious origins. Iran J Microbiol. 2012;4(3):118-23.

41. Nicas TI, Iglewski BH. Production of elastase and other exoproducts by environmental isolates of Pseudomonas aeruginosa. J Clin Microbiol. 1986;23(5):967-9.

42. Cowell BA, Twining SS, Hobden JA, Kwong MS, Fleiszig SM. Mutation of lasA and lasB reduces Pseudomonas aeruginosa invasion of epithelial cells. Microbiology. 2003;149(Pt 8):2291-9.

43. El-Din AB, EL-Nagdy, M.A., Badr, R. and ELSabagh, A.M. Pseudomonas aeruginosa exotoxin A: its role in burn wound infection and wound healing. Egypt J Plast Reconstr Surg. 2008;32:59-65.

44. Hummel A, Unger G. Detection of Pseudomonas aeruginosa in bronchial and tracheal aspirates by PCR by amplification of the exotoxin A gene. Zentralbl Hyg Umweltmed. 1998;201(4-5):349-55.

45. Ben Haj Khalifa A, Moissenet D, Vu Thien H, Khedher M. [Virulence factors in Pseudomonas aeruginosa: mechanisms and modes of regulation]. Ann Biol Clin (Paris). 2011;69(4):393-403.

46. Heidary Z, Bandani E, Eftekhary M, Jafari AA. Virulence Genes Profile of Multidrug Resistant Pseudomonas aeruginosa Isolated from Iranian Children with UTIs. Acta Med Iran. 2016;54(3):201-10.

47. Mitov I, Strateva T, Markova B. Prevalence of virulence genes among bulgarian nosocomial and cystic fibrosis isolates of pseudomonas aeruginosa. Braz J Microbiol. 2010;41(3):588-95.

48. Al-Dahmoshi H. O. M, Al-Khafaji N. S, Jeyad A. A, Shareef H. K, F. A-JR. Molecular Detection of Some Virulence Traits Among Pseudomonas aeruginosa Isolates, Hilla-Iraq. Biomed Pharmacol J. 2018;11(2). 
49. Tumbarello M, De Pascale G, Trecarichi EM, Spanu T, Antonicelli F, Maviglia R, et al. Clinical outcomes of Pseudomonas aeruginosa pneumonia in intensive care unit patients. Intensive Care Med. 2013;39(4):682-92.

50. Al-Wrafy F, Brzozowska E, Gorska S, Gamian A. Pathogenic factors of Pseudomonas aeruginosa - the role of biofilm in pathogenicity and as a target for phage therapy. Postepy Hig Med Dosw (Online).2017;71(0):78-91.

51. Chatterjee M, Anju CP, Biswas L, Anil Kumar V, Gopi Mohan C, Biswas R. Antibiotic resistance in Pseudomonas aeruginosa and alternative therapeutic options. Int $\mathrm{J}$ Med Microbiol. 2016;306(1):48-58.

52. Fu W, Forster T, Mayer O, Curtin JJ, Lehman SM, Donlan RM. Bacteriophage cocktail for the prevention of biofilm formation by Pseudomonas aeruginosa on catheters in an in vitro model system. Antimicrob Agents Chemother. 2010;54(1):397-404.

53. Wessel AK, Liew J, Kwon T, Marcotte EM, Whiteley M. Role of Pseudomonas aeruginosa peptidoglycanassociated outer membrane proteins in vesicle formation. J Bacteriol. 2013;195(2):213-9. 